\title{
Building a Fascist Romania: Voluntary Work Camps as Mobilisation Strategies of the Legionary Movement in Interwar Romania
}

\author{
Raul Cârstocea \\ Europa University Flensburg \\ raul.carstocea@uni-flensburg.de
}

\begin{abstract}
This paper addresses the importance of work camps as mobilisation strategies employed by the 'Legion of the Archangel Michael', Romania's interwar fascist movement. It argues that the success of the legionary constructive work projects, practically taking the form of voluntary work camps and smaller 'construction sites' (şantiere) - the latter developed according to similar principles, yet more limited in size - contributed significantly to the increase in popularity of the movement, in spite of (and perhaps even aided by) sustained opposition from the state authorities. As such, the case study of the legionary work camps is employed in an attempt to show how grassroots mobilisation strategies, emphasising activism and voluntarism, as well as cross-class solidarity among members of the movement, added considerable credibility to a populist palingenetic project, circumventing a shortage of material resources that prevented the use of more elaborate propaganda methods. Such strategies rendered the legionary movement distinct from all the other political parties in interwar Romania, and their positive reception, especially among the rural population, gave credence to the legionary criticism of the democratic parties and, implicitly, to the movement's challenge to parliamentary democracy.
\end{abstract}

\section{Keywords}

Romania - fascism - Iron Guard - camps - propaganda

\footnotetext{
* The research for this article was made possible by a generous grant from the Vienna Wiesenthal Institute for Holocaust Studies.

(C) CÂRSTOCEA, 2017 | DOI 10.1163/22116257-00602002
}

This is an open access article distributed under the terms of the prevailing CC-BY-NC License at the time of publication. 
In the study of fascism, considerable attention has been dedicated both to the intellectual roots of fascist ideology and to the organisational features and propaganda style that have often been described as characteristic of it. Stanley Payne's model of generic fascism encompasses both a new ideological orientation and 'common political goals' and 'common aspects of style, and somewhat novel modes of organization', as well as a list of 'fascist negations' which could however be included within the former category. ${ }^{1}$ Roger Griffin's famous synthetic definition of fascism as 'a genus of political ideology whose mythic core in its various permutations is a palingenetic form of populist ultranationalism'2 also incorporates both ideological and propagandistic aspects. Arguing that the two ought to be treated separately but without failing to note that the latter were often derived from the former, Roger Eatwell called for a distinction between fascist ideology and propaganda, as well as for exploring the interplay between the two, the ways in which the principles upheld by fascist movements were essentially influenced by the historical and socioeconomic context in which they were developed, as well as for differentiating between the 'esoteric and exoteric appeal' of fascist groups. ${ }^{3}$ It is along these lines that an exploration of the nexus of ideology and propaganda in the case of the 'Legion of the Archangel Michael' or Iron Guard, Romania's interwar fascist movement, might shed some light on the spectacular growth in popularity of an organisation that developed in the space of a decade from a group of five students to the only lasting mass movement in Romania's history and the third

1 Stanley Payne, A History of Fascism, 1914-1945 (Madison: University of Wisconsin Press, 1995), 6.

2 Roger Griffin, The Nature of Fascism (London: Routledge, 1993), 26. In this article, the use of the concept 'populism' is limited to the specific context of fascism and follows Roger Griffin's interpretation of it. Consequently, even when not directly specified as such, it is to be understood in conjecture with the ultra-nationalism of fascist movements, as a type of appeal to the 'common man' as the 'authentic' repository of the values of the 'nation', entailing an anti-establishment impetus (translated into opposition to traditional ruling elites) and a recourse to 'people power' as a source of legitimacy. At the same time, this hyphenated understanding of the concept is also to be viewed in the context of the perpetual tension between populist rhetoric and the elitism characteristic of fascist organisations, epitomised by the importance of paramilitary elites and the leader cult. Thus, such an interpretation of 'populism' is distinct both from that associated with some of its specific historical forms (e.g. the late nineteenth century Populist Party in the United States) or some of its contemporary understandings (e.g. Cas Mudde's influential view of populism as 'a thin-centered ideology'). See Griffin, The Nature of Fascism, 36-42; Cas Mudde, Populist Radical Right Parties in Europe (Cambridge: Cambridge University Press, 2007), 23.

3 Roger Eatwell, 'Towards a New Model of Generic Fascism,' Journal of Theoretical Politics 4 (1992): 162, 172-174. 
largest fascist organisation in Europe. ${ }^{4}$ As such, the present analysis departs from the tradition of theoretical interpretations of fascism that focus primarily on the intellectual roots of fascist ideology, 5 to adopt a more practice-oriented approach to understanding the specific strategies that contributed to the popularity of fascist movements in the interwar period.

While the existing literature on the importance of propaganda for the legionary movement is considerably less extensive than its counterparts that address the Fascist regime in Italy or the Nazi one in Germany, ${ }^{6}$ legionary work camps have benefitted from some recent scholarly attention. ${ }^{7}$ These recent interpretations nuanced the view of work camps expressed in earlier studies of the Legion, which saw them primarily as 'tools of legionary propaganda', focusing instead on their importance within the legionary educational project, both physical and spiritual. The present paper aims to combine the different approaches that have been applied so far to the case study of legionary work camps, returning to a focus on their propaganda value while also paying close attention to their perception by legionaries, as practical expressions of a palingenetic project aimed at a radical transformation of Romanian society.

4 Payne, A History of Fascism, 275-277; Armin Heinen, Legiunea 'Arhanghelul Mihail': O contribuţie la problema fascismului internaţional [The Legion of the Archangel Michael: A Contribution to the Problem of International Fascism], (Bucureşti: Humanitas, 2006), 357.

5 See for example Noël O'Sullivan, Fascism (London: Dent, 1983); Zeev Sternhell, Mario Sznajder and Maia Asheri, The Birth of Fascist Ideology: From Cultural Rebellion to Political Revolution (Princeton: Princeton University Press, 1994); George Mosse, The Fascist Revolution: Toward a General Theory of Fascism (New York: Howard Fertig, 1999).

6 See for example George Mosse, Nazi Culture: Intellectual, Cultural and Social Life in the Third Reich (London: W.H. Allen, 1966); David Welch, The Third Reich: Politics and Propaganda (London: Routledge, 1993); Simonetta Falasca-Zamponi, Fascist Spectacle: The Aesthetics of Power in Fascist Italy (Berkeley: University of California Press, 1997); Ruth Ben-Ghiat, Fascist Modernities: Italy, 1922-1945 (Berkeley: University of California Press, 2001).

7 Rebecca Haynes, 'Work Camps, Commerce and the Education of the "New Man" in the Romanian Legionary Movement,' The Historical Journal 51 (2008): 943-967; Valentin Săndulescu, "Taming the Body": Preliminary Considerations Concerning the Legionary Work Camps System (1933-1937),' Historical Yearbook 5 (2008): 85-94; Roland Clark, Holy Legionary Youth: Fascist Activism in Interwar Romania (Ithaca: Cornell University Press, 2015), 154-162.

8 Haynes, 'Work Camps,' 944. For examples of such views of legionary work camps as propaganda tools, see Francisco Veiga, Istoria Gărzii de Fier 1919-1941: Mistica ultranaţionalismului [The History of the Iron Guard 1919-1941: The Mysticism of Ultra-nationalism], (Bucureşti: Humanitas, 1993), 219-222; Nicholas Nagy-Talavera, The Green Shirts and the Others: A History of Fascism in Hungary and Romania (Iaşi and Oxford: Center for Romanian Studies, 2001), 397-398, 402-406; Heinen, Legiunea, 210-211, 260-262. 
Following a short presentation of the history of the establishment of legionary work camps, the article will analyse their propaganda value in relationship to the ideology of the movement, as well as to the specific contextual constraints it faced. Exploring their emergence among the nationalist student movements that constituted the nucleus of the Legion, antedating its establishment, the article will first show that their development was as much driven by necessity (dictated by the lack of funds for standard electoral propaganda) as it was the result of choices made by legionary leaders (who, often coming from a rural background, understood that in a predominantly rural country the modern methods of propaganda via the media were less effective than direct contact with the population). Subsequently, given the sympathy of the population for what were presented as examples of altruistic commitment to the greater good and of solidarity between people from different social backgrounds and regions of Romania, the work camps were conceptualised as practical applications of the principles of the movement, a demonstration of the workings of its ideology in practice. In that respect, they were re-coded back into legionary rhetoric as exemplary practices for a voluntaristic, activist ideology that was perceived as rendering the movement distinct from all other political organisations in interwar Romania.

On another level, the constructive work projects were employed to counterbalance the extreme political violence that was also a trademark of the movement. To the justified accusations of promoting armed paramilitary groups, of political terrorism, and of carrying out or instigating anti-Semitic pogroms, the movement could oppose the image of a group carrying out peaceful constructive activities, while being persecuted for it by the police. This allowed the movement to uphold its image of a positive political force that was being unjustly persecuted and to reinterpret its own violent actions as mere reactions to the brutality of the authorities, something that once again the majority rural population was very accustomed with, particularly during electoral campaigns. Eventually, the clashes with the authorities and the increasing opposition by the state to what was effectively an alternative, non-state project of modernising Romania only contributed to the popularity of a movement whose populism made it prone to self-identification as the 'authentic' representative of 'the people'.

\section{The Origins of a Practice: The First Work Camp}

Before the establishment of the 'Legion of the Archangel Michael', its future founders - and especially the Legion's undisputed leader, Corneliu Zelea 
Codreanu - had achieved public notoriety due to their violent activism in the ranks of anti-Semitic student organisations. Backed up by an extensive anti-Semitic legacy in nineteenth century Romania that effectively prevented Jewish emancipation until the First World War, ${ }^{9}$ the student movement had achieved prominence in the context of 'an unprecedented expansion in educational facilities [that] increased the number of students to a record level, ${ }^{10}$ as well as of the parliamentary debates surrounding the voting of a new constitution that finally granted citizenship to Jews in Romania. Both aspects were directly related to the aggressive project of cultural nationalisation that the postwar enlarged Romanian state embarked upon in an attempt to homogenise and integrate the newly acquired territories, where the majority of ethnic Romanians had often been in a subordinate position to dominant minorities. ${ }^{11}$ In light of their overrepresentation in Romanian universities with respect to their proportion of the population, as well as of an erroneous association of the Jewish refugees escaping the Civil War in the Soviet Union with Bolshevik propagandists, ${ }^{12}$ the Jewish minority was singled out as a target by nationalist Romanian students, who argued against emancipation and called for the implementation of numerus clausus in the universities. ${ }^{13}$

While the period before the war had witnessed legal discrimination of the Jews, coupled with a virulent anti-Semitic discourse promoted by some of the country's most prominent politicians and intellectuals, the early 1920 brought to the fore numerous incidents of anti-Semitic violence, carried out primarily by nationalist students. ${ }^{14} \mathrm{~A}$ movement of protest against the proposed granting

9 Raul Cârstocea, 'Uneasy Twins? The Entangled Histories of Jewish Emancipation and Anti-Semitism in Romania and Hungary, 1866-1913, Slovo 21 (2009): 64-85.

10 Constantin Iordachi, 'Charisma, Religion, and Ideology: Romania's Interwar Legion of the Archangel Michael,' in Ideologies and National Identities: The Case of Twentieth-Century Southeastern Europe, ed. John Lampe and Mark Mazower (Budapest: Central European University Press, 2003), 22.

11 For an excellent account of this project, involving significant expansion and reforms of the higher education system, see Irina Livezeanu, Cultural Politics in Greater Romania: Regionalism, Nation-Building, and Ethnic Struggle, 1918-1930 (Ithaca: Cornell University Press, 1995).

12 Livezeanu, Cultural Politics, 253-255.

13 Ion I. Moţa, 'Cauza noastră e justă în ordinea morală şi serveşte progresul social,' [Our Cause is Just in the Moral Order and Serves Social Progress], Dacia nouă [New Dacia], 22 December 1922.

14 'Excesele de la Cluj' [The Cluj Excesses], Aurora, 2 December 1922; 'Acţiunea studenţilor naţionalişti' [The Action of Nationalist Students], Lumea [The World], 9 December 1922; 'Membrii Marelui Colegiu Universitar şi agitaţiile antisemite' [The Members of the Great University Board and the Anti-Semitic Agitations], Lumea, 10 December 1922. 
of citizenship rights to all Jews in Romania, which spread across all university centres in the country in December 1922, eventually led to the establishment of the Liga Apărării Naţional-Creştine [LANC; League of National Christian Defence] on 4 March $1923 .{ }^{15}$ Fundamentally an anti-Semitic organisation, as the name suggests, the League was led by Alexandru C. Cuza, Dean of the Faculty of Law at the University of Iaşi and a representative of the 'old generation' of Romanian anti-Semites; Corneliu Zelea Codreanu, twenty-three years old at the time, was appointed national leader of its youth section. Despite the close connections between the two, a dispute over the organisation of the new movement ensued from the outset. While Cuza envisioned LANC as a political party functioning within the limits of parliamentary democracy, Codreanu, influenced by the rise of Fascism in Italy, dismissed parliamentary politics altogether and wanted to organise it as a disciplined movement committed to direct action and based on unconditional obedience to the leader. ${ }^{16}$ Meeting with the rebuttal of his mentor, Codreanu decided to take matters in his own hands and in the autumn of 1923, together with five other students, he plotted to assassinate the 'representatives of Jewish power' (more specifically some prominent rabbis, bankers and journalists), as well as the 'traitors' of the national cause who were held responsible for the voting of the new constitution and implicitly for Jewish emancipation. ${ }^{17} \mathrm{~A}$ total of twelve public figures were targeted, six Jewish and six ethnic Romanians, all of the latter government ministers. ${ }^{18}$ The plot was unrealistic and eventually revealed to the police by one of the six students, but the subsequent imprisonment and trial of the other five students brought them to national fame, with various nationalist organisations expressing their support for the 'martyrs of the nation in its struggle against the Jewish invasion.' ${ }^{19}$

According to Codreanu's memoirs, it was during their time in prison that his plans for a new youth organisation, functioning within LANC but with different goals, of 'education and combat', crystallised. ${ }^{20}$ Inspired by an icon from

\footnotetext{
15 Livezeanu, Cultural Politics, 266.

16 Corneliu Zelea Codreanu, Pentru legionari [For My Legionaries] (Sibiu: Editura Totul Pentru Ţară, 1936), 124.

17 Statement of Ion I. Moţa, 9 October 1923. Consiliul Naţional pentru Studierea Arhivelor Securităţii [CNSAs; National Council for the Study of the Securitate Archives], Fond Penal [Penal Fund, henceforth Fund P], File 13207, Vol. 2, 179-180.

18 Arhivele Naţionale ale Republicii Moldova [ANRM; The National Archives of the Republic of Moldova], Fond Direcţia Generală a Poliţiei [DGP; General Police Directorate Fund], File 103/1933, 225.

19 CNSAS, Fund P, File 13207, Vol. 3, 169.

20 Codreanu, Pentru legionari, 179.
} 
the prison chapel, the denomination 'The Archangel Michael' was chosen by Codreanu for this new movement, and although the plans for the new organisation would not materialise until 1927, the five imprisoned students later became the founding members of the legionary movement. ${ }^{21}$ At this time, however, the experience of prison appears to have led them to reconsider their actions and realise that 'violence was not the right way, but self-improvement through creative work and discipline, and above all, faith in God and in oneself - this was to be the wave of the future. ${ }^{22}$

While the statement above was clearly only partially true, as extreme violence remained one of the characteristics of the legionary movement, it was out of this reorientation towards constructive work that the idea of the work camps first developed. Following their acquittal, the first such work project was initiated - addressing an immediate concern of the student body, the insufficient capacity of student dormitories, Codreanu and about twenty of his followers decided to build one themselves. For that purpose, they initially began producing the bricks necessary for the building, in an effort that Codreanu identifies in his memoirs as 'the first work camp'. ${ }^{23}$ Inaugurated on the bank of the river Prut on 8 May 1924 with a religious service, the camp soon fulfilled one of its objectives: demonstrating to the local peasants and workers that intellectuals did not shy away from manual labour, and consequently gaining their support. This initiative can thus be seen as the beginning of the solidarity between intellectuals, peasants and workers that the Legion would later preach, and indeed accomplish to an impressive extent. At the same time, the construction work was also meant to have an educational component, respectively 'the ennoblement of manual work', ${ }^{24}$ a feature that would become characteristic of the later legionary work camps. The lack of funding for the camp led to the establishment of another project, a vegetable garden set up on a one hectare plot donated by Mrs Ghica in Iaşi, where students were to produce the food needed by those working on the bricks. ${ }^{25}$

Work at these camps was, however, not as 'innocent' as it may seem, or as Codreanu presented it in his memoirs. The students who worked at the camp

21 Corneliu Zelea Codreanu, 'Însemnări' [Notes], Pământul Strămoşesc [The Ancestral Land], $2^{\text {nd }}$ series, 1(1952): 16 .

22 Nagy-Talavera, The Green Shirts, 263.

23 Codreanu, Pentru legionari, 200.

24 Horia Sima, The History of the Legionary Movement (Liss: The Legionary Press, 1995), 21 (emphasis in the original; all emphases in the text are in the original, unless specified otherwise).

25 CNSAS, Fond Documentar [Documentary Fund, henceforth Fund D], File 1016o, Vol. 1, $84-85$. 
were also carrying out military instruction under the command of Codreanu, a former graduate of the elite military school at Mănăstirea Dealu. As a result, the Iaşi police, led by its prefect Constantin Manciu, arrested the sixtythree students working in the vegetable garden on 31 May 1924; Codreanu was among them. ${ }^{26}$ The fact that the police prefect of one of the largest cities in Romania participated to the arrest in person clearly demonstrates the importance given to it, highly unusual for a group of students carrying out voluntary work in a vegetable garden. A piece of paper found in Codreanu's pocket at the time of his arrest, handwritten by him, contained an appeal to 'All the Romanian and Christian people between the Prut and the Dniester', urging them to participate in their first mass gathering in Bessarabia, where delegates from the entire country would be present; the appeal began with the following statement: 'For centuries, the Christian soul of the peoples of the world is agonising in suffering and sorrow under the insult, the whip lash and the axe strike of Judas!'27 This statement demonstrates that under the guise of peaceful voluntary work, nationalist students were still instigating the population towards violent anti-Semitic action. On the other hand, as was the case with many later attempts at setting up work camps, the reaction of the authorities was swift and unduly brutal, causing a shift in public opinion towards a favourable view of the nationalists. ${ }^{28}$

\section{In Search of a New Propaganda Style}

As a result of the intervention of the police, this first voluntary work project was terminated, to be resumed and completed only in 1928, after the establishment of the 'Legion of the Archangel Michael. ${ }^{29}$ By that time, the events occurring in the aftermath of the students' arrest had received considerably more public attention that the work project itself. In a personal vendetta against the police prefect he held responsible for the arrest, imprisonment and torture of the nationalist students, Codreanu assassinated him on 25 October $1924 .{ }^{30}$

26 CNSAS, Fund P, File 13207, Vol. 3, 266-302.

27 Ibid., 250-251.

28 'Poliţia din Iaşi: Studenţii au fost bătuçi de însuşi prefectul poliţiei' [The Iaşi Police: Students Were Beaten by the Police Prefect Himself], Universul [The Universe], 8 June 1924; 'Iaşii sub teroarea prefectului de poliţie' [Iaşi under the Terror of the Police Prefect], Universul, 10 June 1924.

29 Haynes, 'Work Camps,' 946-947.

30 CNSAS, Fund P, File 13207, Vol. 1, 176-177, 180-181. 
Paradoxically, his trial and eventual acquittal brought him national acclamation rather than opprobrium, implicitly sanctioning the recourse to violence that was to become characteristic of the legionary movement. The surge in Codreanu's popularity, coupled with his feeling that this had been insufficiently exploited for propaganda purposes by the LANC leadership, served to deepen the rift between him and his former mentor, A.C. Cuza, leading to an eventual split in 1927 and the establishment of the Legion. ${ }^{31}$ Importantly, in an unpublished letter sent to Cuza from Grenoble on 21 January 1926, Codreanu, while acknowledging Cuza's merits as a theoretician of the 'national idea', accused him of being incapable of organising a 'national movement' for action and even claimed that the original initiative behind the foundation of LANC was his own. Codreanu concluded the letter by re-emphasising his notion of 'integral discipline' and the primacy of actions ('deeds' in his own terms) over ideas. ${ }^{32}$ These aspects were indeed to prove of paramount importance for the ideology, organisation and propaganda strategies of the legionary movement.

Initially, except for the more pronounced religious terminology employed in its rhetoric, the legionary movement did not introduce many novel elements in terms of ideology as compared to LANC. This was actually a position explicitly assumed by the movement's founders, who identified the relationship of the Legion with LANC as 'very close, because the Legion was born precisely due to the split in the League and just for the purpose of saving the national movement from total defeat'. ${ }^{33}$ As already indicated by Codreanu at the time of his split from LANC, the novelty of the new organisation resided mostly with its organisational principles and mobilisation strategies, which were eventually to prove much more successful for attracting new recruits than the traditional political propaganda practices employed by the League. The first such innovation was the cellular organisation of the legionary movement, in groups of three to thirteen members, initially referred to as 'nuclei' ${ }^{34}$ and later as 'nests' ${ }^{35}$ These were to act autonomously from one another, and had a leader who was neither to be elected nor appointed, but to assume leadership as a result of his native leadership skills, recognised and acknowledged by the nest's members. As they increased in number, the nests organised themselves in networks, at the level

\footnotetext{
31 Codreanu, Pentru legionari, 251, 295-296.

32 CNSAs, Fund P, File 11784, Vol. 18, 174-175.

33 Corneliu Zelea Codreanu et al., 'Legiunea Arhanghelul Mihail' [The Legion of the Archangel Michael], Pământul Strămoşesc, 15 August 1927.

34 Corneliu Zelea Codreanu et al., 'Organizarea Legiunii Arhanghelul Mihail' [The Organisation of the Legion of the Archangel Michael], Pământul Strămoşesc, ${ }_{5}$ September 1927.

35 Codreanu, Pentru legionari, 336.
} 
of the village or city, province, county, and region. ${ }^{36}$ The corresponding cells in the women's organisation were known as cetăţui [fortresses] ${ }^{37}$ Both nests and fortresses were organised along paramilitary lines, and were described by a police report as 'a legionary army [established] on fascist doctrinal bases.' ${ }^{38}$ This bottom-up, grassroots approach to the organisation of the movement was very well-suited for a small splinter group, virtually insignificant in terms of either following or resources, and certainly unable to compete for the nationalist vote with the much better established LANc. Unable to offer any tangible rewards to its followers and having to rely almost exclusively on voluntary contributions for its functioning, the legionary movement successfully managed to convert weakness into virtue, emphasising the altruism and commitment to the nationalist cause of its followers, who sacrificed precious resources to ensure the organisation's continued existence. ${ }^{39}$

The first inroads towards popularity after the initial slow start in the movement's development were due primarily to the new propaganda style it adopted. Prompted partly by necessity and the shortage of funds, but recoded rhetorically as practices meant to accustom its members to hardship, effort, severity, silence, and responsibility, the first legionary marches in the winter of 1929-1930 met with a very favourable reception among the rural population. In

$36 \quad$ Ibid., $336-337$.

37 Corneliu Zelea Codreanu, Cărticica şefului de cuib [The Nest Leader's Manual], (Bucureşti: Editura Mişcării Legionare, 1940), 15-20.

38 Arhivele Naţionale Istorice Centrale [The National Central Historical Archives], Fond Direcţia Generală a Poliţiei [DGP; General Police Directorate Fund], File 232/1935, Vol. 2, 68-69.

39 The activity of the legionary movement between 1927 and 1930 was unmistakably marked by the lack of funding with which the organisation was confronted. The first action of the movement, defined as a 'battle' in the typically military terminology employed by Codreanu, had been an appeal to subscriptions that would ensure the publication of the only legionary newspaper, 'The Ancestral Land', and many similar appeals for contributions can be encountered in its pages. In spite of these efforts, only one issue of Pământul Strămoşesc appeared in 1929, the Legion did not manage to secure funds for building their headquarters, and their only motorised vehicle, a pick-up truck nicknamed Căprioara [The Deer], was used more as a taxi or for transporting vegetables than for propaganda. See for example Corneliu Zelea Codreanu, 'Activitatea Legiunii pentru cei care sunt in Legiune şi pentru cei care doresc să fie. Un apel la muncă' [The Activity of the Legion for Those Who Are in the Legion and for Those Who Wish to Be: An Appeal to Work], Pământul Strămoşesc, 1 September 1927; 'Munca noastră' [Our Work], Pământul Strămoşesc, 1 November 1927; 'Rezultatul muncii noastre: A doua bătălie' [The Result of Our Work: The Second Battle], Pământul Strămoşesc, 1 February 1928; Codreanu, Pentru legionari, 347-349; Heinen, Legiunea, 132-133. 
line with Codreanu's appeal to 'step out to the masses', ${ }^{40}$ legionaries marched on foot or on horseback through the villages of Bessarabia, wearing the traditional peasant costume and making extensive use of religious symbolism in both their speeches and appearance. One such propaganda tour, initiated by Codreanu and twenty of his followers in January 1930, concluded with a meeting on 3 February 1930 that was attended by approximately 13,000 people, with Codreanu's escort numbering $18 \mathrm{o}$ horse riders. ${ }^{41}$ Proven successful, the method was to be employed for electoral propaganda, and while the movement was not able to gain access to Parliament in the general elections of May 1931, it managed to win two by-elections in the counties of Neamţ and Tutova, in August 1931 and April 1932 respectively, sending both Corneliu Codreanu and his father, Ion Zelea Codreanu, to Parliament as representatives of the movement. ${ }^{42}$ The specific conditions of the second by-election, following a particularly cold winter which prevented the deployment of the more sophisticated propaganda apparatus of the major parties and favoured the legionaries, who impressed the population by a three hundred kilometre march on foot from Bucharest to Bârlad and by their stubborn resistance to the violence of the authorities, represented further proof of the viability of the propaganda methods employed by the legionary movement, all the more important since this was the first victory the organisation registered in direct competition with LANC, the rival nationalist, anti-Semitic party. ${ }^{43}$

The growing popularity of the Legion was proven by the results of the July $193^{2}$ general parliamentary elections. In the space of one year, the organisation more than doubled its votes, obtaining $2.37 \%$ of the vote and sending five representatives to parliament: Corneliu Zelea Codreanu, Ion Zelea Codreanu, Constantin (Nuţu) Eşanu, Mihail Stelescu, and Ion Neculce. ${ }^{44}$ Moreover, the popularity of the movement was also reflected in the extension of its electoral participation in the territory: in 1931, the legionaries had registered lists of candidates in seventeen counties; one year later, they did so in thirty-six counties. ${ }^{45}$ Referring to the propaganda methods employed by the two nationalist organisations, police reports noted that

\footnotetext{
40 Codreanu, Pentru legionari, 364 .

41 ANIC, Fond Ministerul de Interne, Diverse [Fund Ministry of the Interior, Varia, henceforth Fund MI ], File 9/1927, 319-320.

42 ANIC, Fond Parlament [Fund Parliament, henceforth Fund PR], File 2374/1932, Vol. 1, 6, 9, 14-15.

43 Ibid.

44 ANIC, Fund PR, File 2374/1932, Vol. 2, 475, 481-484.

45 Codreanu, Pentru legionari, 433.
} 
the superiority, as compared to LANC, of the votes of Corneliu Zelea Codreanu is due to the intense and permanent propaganda he carries out in the villages with his devoted cohorts; the peasants are impressed by their visits ..., and they [the legionaries] know how to reach their souls, enquiring about all their needs, sitting around a boiling pot of soup or polenta. Taking their time, they can speak of everything, [as] the peasant has many needs and troubles, which he cannot hastily tell. His trust once gained, the peasant is won [to their cause] forever. ${ }^{46}$

A similar report refers to Codreanu himself visiting a cattle fair and personally meeting the peasants, listening to their grievances, and collecting their petitions. ${ }^{47}$ Such encounters with leaders of a political group were extremely rare in interwar Romania. Traditional parties relied on professional propagandists, and their leaders were too remote from the world of the village to even consider such contacts. The legionaries, with their peasant costumes and, in many cases, a peasant background, appeared much closer to the reality of 'the people' in a country where more than $70 \%$ of the population was involved in agriculture. As a result, another police report described the propaganda strategy as 'impressive', 'much more efficacious than that of others', and concluded that 'the Iron Guard organisation is in full progress and, if it persists under the current form, it stands only to gain from it'.48

The populist grassroots features of the legionary propaganda style thus brought the movement its first electoral successes and would be maintained throughout its existence. At the same time, the similarity of legionary propaganda with that of other fascist movements was also noted by police reports, which stated that 'Codreanu is much closer to Hitler, as he works practically, whereas Cuza is doctrinary. This explains the fact that [Cuza], although he has been active for forty years, has not made any progress, whereas Codreanu, in a relatively short time, has gained an important number of adherents. ${ }^{49}$ Indeed, from the virtually insignificant organisation that counted less than four hundred members in January $1929,{ }^{50}$ by 1933 the Legion had become a force

46 CNSAS, Fund P, File 11784, Vol. 14, 80.

47 CNSAS, Fund P, File 11784, Vol. 2, 94.

48 ANIC, Fund Mi, File 4/1932, 560-561. The Iron Guard had been established on 12 April 1930 as an umbrella organisation meant according to Codreanu's intentions 'to combat Judaic communism, in which the 'Legion of the Archangel Michael' and any other youth organisations could enter, across party affiliations'. Codreanu, Pentru legionari, 377. Since no other organisation joined, the two denominations eventually overlapped.

$5^{\circ}$ Sima, The History, $5^{6}$. 
to be reckoned with, and its propaganda style, a novelty in interwar Romania, contributed significantly to its growing popularity.

\section{A Practice Reborn: A History of the Work Camps in the 1930s}

The increase in popularity of the Legion, together with its visible similarity to other fascist movements, brought it ever more attention from the authorities, which attempted to contain it. If until 1930 the movement was virtually unmentioned in police reports, which concentrated on the much better organised LANC, the situation changed in the 1930s, when the Legion was quite rightly recognised as the most significant right-wing threat to democracy in interwar Romania. As a result, the movement was repeatedly made illegal, with the first such official dissolution occurring on 2 January 1931, by order of the Ministry of the Interior. ${ }^{51}$ The Legion however managed to circumvent all these bans, which did not even prevent it from attracting more members to its ranks, partly due to its cellular organisation which allowed it to effectively activate as an underground organisation in times of persecution, and partly to the general instability of Romanian politics at the beginning of the 1930 s. $^{52}$

In an attempt to counteract accusations regarding its extreme violence and militarism and to turn a predominantly negative public opinion to its favour, the legionary leadership decided to return to the practice of voluntary work projects as a propaganda strategy. On 15 July 1933, a police report noted that 'with the purpose of increasing its popularity in the countryside, of improving the prestige of the movement in the eyes of public opinion, and of discrediting the measures taken by the government against the movement, the Iron Guard decided that this summer the members of its organisations will execute a few large-scale works of general interest. ${ }^{53}$ In the first of these projects, legionary teams were deployed to build a two and a half kilometre dam on the Buzău

$51 \quad$ ANIC, Fond Preşedinţia Consiliului de Miniştri [Fund Presidency of the Council of Ministers, henceforth fund PCM], File 28/1931-1932, 8.

$5^{2} \quad$ The very fact that general elections were held every year between 1931 and 1933 is indicative of the general atmosphere of political instability in the country, prompted in part by the crisis ensuing upon the return and restoration of King Carol II. In fact, as Armin Heinen notes, the stagnation of the legionary movement between 1927 and 1930 can also be partly explained by the popularity at this time of the National Peasant Party, especially among the rural population. If in 1928 the party had won a landslide victory in the elections, by 1930 it was largely compromised, due to corruption scandals and its ambiguous position vis-à-vis the return of King Carol II. See Heinen, Legiunea, 129.

ANIC, Fund MI, File 4/1933, 113. 
River, near the village of Vişani in Râmnicu Sărat County, to prevent the yearly floods that affected the area. The work was to be carried out over a period of two months, by two legionary teams of five hundred members each, led by the pharmacist Aristotel Gheorghiu, leader of the Râmnicu Sărat chapter of the organisation. ${ }^{54}$ However, since the project lacked official authorisation, the police arrested the ninety-one legionaries who were the first to arrive at the site from Bucharest, before they even reached the village. ${ }^{55}$ Although the project was most likely unfeasible, as the legionary movement lacked both the materials and the engineering expertise for such a large-scale construction, the arrest of young people who had come on foot to volunteer their time and effort for the public good provided the movement with yet another opportunity for protest. ${ }^{56}$ Sympathisers of the movement pointed out that the initiative of the legionaries came in response to the countless unfulfilled electoral promises of the democratic parties to build the dam, and that such altruistic commitment was repaid with police brutality and arbitrary arrest. ${ }^{57}$ An open letter of protest published by Codreanu emphasised the violence of the authorities and the humiliations to which the legionary volunteers - including the priest Ion Dumitrescu, a cleric who was also a legionary commander - were subjected. ${ }^{58}$

Undeterred by the failure of this project, in August 1933 Codreanu urged the members of the movement to build a 'rest home' for legionaries in a suburb of Bucharest. Known initially as the 'House of Wounded Legionaries', the building, completed only in 1936, was eventually to become the so-called 'Green House', the central headquarters of the movement. ${ }^{59}$ At this time the Legion was making considerable inroads in terms of popularity among young intellectuals, and the group formed around the Axa [The Axis] journal, based in Bucharest, enthusiastically supported the work project. Articles written by Mihail Polihroniade and Alexandru Cantacuzino, prominent legionary intellectuals, juxtaposed the 'heroism' of the legionary initiative, illustrating 'the value of collective effort, the discipline of obscure work, the ardour of anonymous

\footnotetext{
$54 \quad$ Ibid., 114 .

55 Ibid., 115 .

$5^{6}$ The police report dealing with this issue notes the initial scepticism of the population about the construction - 'because these works necessitate, in addition to volunteers, very many materials that the Iron Guard cannot have'. Ibid., 116.

57 Constantin Popov, 'Digul' [The Dam], Axa, 1 August 1933.

$5^{8}$ Corneliu Zelea Codreanu, 'Prigoana împotriva "Gărzii de Fier"' [The Persecution of the 'Iron Guard'], Calendarul [The Calendar], 20 July 1933.

59 Mihail Polihroniade, 'Construim!' [We Build!], Axa, 6 September 1933; Haynes, 'Work Camps,' 947.
} 
sacrifice' 60 with the alleged 'despicable decadence' and 'vile exploitation' of the government, on whose initiative a Bucharest park that commemorated King Carol I, the founder of the modern Romanian state, had been transformed into an entertainment venue. ${ }^{61}$ Presented together with photographs from the work camp meant to illustrate both the hardship of the work and the discipline of the volunteers, ${ }^{62}$ the articles also emphasised the cross-class solidarity of 'intellectuals who toil next to manual workers', adding to it praise for 'members of Parliament such as Corneliu Codreanu and the admirable Mihail Stelescu who think that the humble example of constructive work takes precedence over democratic verbiage. ${ }^{63}$ These were the first intimations of the ideological recoding of the constructive work projects, consistently presented in legionary texts as an alternative to the alleged decadence and corruption characterising the activities of the democratic parties. Although the construction work at the future legionary headquarters was eventually also discontinued following the intervention of the authorities, the blueprint of the work camps had been established and was developed further in the summer of 1934, when new camps were set up at Giuleşti, another suburb of Bucharest (producing bricks and growing vegetables), at Chitila, also a suburb of Bucharest (where legionaries produced 100,00o bricks intended for the construction of a church), at Dealul Negru in Transylvania (building a school), at Cotiugenii Mari, in Bessarabia (rebuilding a ruined church), at Mount Rarău in Bukovina (building another 'rest home' for legionaries), and at Movila-Techirghiol in Dobrogea (also a 'rest home', although this project would be expanded in the following summer to become the largest of all legionary work camps, the Carmen Sylva one). ${ }^{64}$

\footnotetext{
6o Polihroniade, 'Construim!'

61 Alexandru Cantacuzino, 'De la Parcul Carol la Bucureştii Noi' [From the Carol [I] Park to New Bucharest], Axa, 15 October 1933.

62 'Casa Legionarilor Răniţi' [The House of Wounded Legionaries], Axa, 1 October 1933.

63 Polihroniade, 'Construim!'

64 George Beza, 'Şcoala de educaţie şi muncă legionară: Istoricul taberelor de muncă voluntară' [The School of Legionary Education and Work: The History of the Voluntary Work Camps], Revista Mea [My Magazine] 1 (1935): 3. Sima, The History, 164-165. The expansion of the practice of setting up work camps in 1934 can also be understood by taking into account the political climate following the murder of Prime Minister Ion G. Duca in December 1933 by a team of legionaries, the most high-profile assassination the movement had carried out to date, and the subsequent arrest and trial of its leadership. Faced with a formal ban on its regular political activities and a negative public opinion, the legionary leadership turned, as in the 1920s, to constructive work as an attempt to counter-balance its extreme violence.
} 
Work camps were thus set up in 1934 in all of Romania's provinces, anticipating the country-wide expansion of this practice in the summers of 1935 and 1936.

In a circular order dated 31 May 1935, entitled 'The Duty of the Student' and written in anticipation of the summer holidays when most of the work projects were carried out, Codreanu set out the basic organisational principles for the work camps and the smaller şantiere [construction sites]. The former were meant to involve a minimum number of thirty legionaries, carrying out a work project with a duration of at least one month. They were led by a legionary commander and also had at least one 'legionary missionary', responsible for the 'spiritual education of the legionaries'; both the commander and the missionary were appointed by the central leadership of the organisation. ${ }^{65}$ The smaller şantiere entailed a work of minimum three days, carried out by a minimum of five legionaries, under the command of a nest leader. The important distinction between the two was that whereas the work camps had an explicitly educational character, a 'legionary school', the latter did not, and were simply meant as examples of a 'public good that legionaries do without asking anyone for anything in exchange'.66 More limited in scope and purpose, the smaller construction sites did not require prior approval from the centre, and the nest leaders involved in such undertakings were merely asked to notify the leadership of their initiative, undoubtedly so that even such minor local projects could be made public.

The number of work camps expanded significantly in the summers of 1935 and 1936 , with the latter being proclaimed by the legionary leadership 'the year of the work camp' ${ }^{67}$ If in 1935 the number of work camps grew from six to at least sixteen, ${ }^{68}$ it was the summer of 1936 that witnessed the most considerable expansion of the system. While a Siguranţa report dating from October 1936 describes in detail the sixty-one work camps established by $3 \mathrm{July},{ }^{69}$ another report dating from 1937 that summarizes the activities and propaganda of the legionary movement in the last six months of 1936 mentions no less than

65 Codreanu, Circulări şi manifeste [Circulars and Manifestoes] (Madrid: Colecţia Omul Nou, 1951), 39-42 (41).

66 Codreanu, Circulări şi manifeste, 41.

67 Haynes, 'Work Camps,' 947.

68 Beza, 'Şcoala,' 4-7. Beza's article provides details of all sixteen work camps he mentions. Horia Sima, leader of the legionary movement after Codreanu's death, claims in his History of the Legionary Movement that there were twenty work camps operating in 1935, without however identifying them. Sima, The History, 165.

69 ANIC, Fund MI, File 6/1936, 248-268. Siguranţa was the name of the political police in interwar Romania, the precursor to the notorious Securitate established by the communist regime in 1948. 
130 work camps. ${ }^{70}$ The latter report, representing archival data that became available only recently, shows that the number of work camps in 1936 was almost double that of the highest estimate cited so far in the secondary literature dealing with this issue, and thus that the work camps system was much more extensive than previously thought. ${ }^{71}$

A breakdown of this data is extremely helpful for illuminating some of the patterns that were characteristic of the legionary work camps. As such, it is noteworthy that of the 128 work camps whose purposes are mentioned in the Siguranţa report (for two of the camps, the nature of the work is not specified), no less than fifty (or $39 \%$ of the total) involved constructions with religious purposes or involving ecclesiastical property. The most common of these, representing more than half of the total, involved the building of churches, while the rest entailed construction or repair work at parish houses, chapels, monasteries, bell towers, or village cemeteries; the erection of large crucifixes was a very popular practice for the smaller şantiere. Of the work projects that did not involve structures with an explicitly religious purpose, the making of bricks for various buildings was the most popular activity, while other projects were aimed at building cultural centres, roads, bridges, houses for poor or afflicted villagers, primary schools, legionary headquarters, houses of rest, student homes, cabins for skiers, mausoleums for soldiers fallen in the First World War, a hospital, a channel meant to deviate the course of a river and prevent floods, and a monument for 'legionary heroes.' ${ }^{72}$

Analysing this data in light of the urban / rural divide also allows drawing some interesting conclusions. Of the 130 work camps in operation in 1936, only fourteen (slightly more than $10 \%$ of the total) were established in towns or cities, with the overwhelming majority of projects targeting the countryside. This was an even more pronounced feature in the case of the construction sites. In an article dealing with work camps and şantiere, Ion Ţurcan, a legionary commander, wrote that the 'construction sites are initiated and led by peasants.

70 CNSAS, Fond Informativ [Information Fund, henceforth Fund I], File 257486, Vol. 2, 377-394. The doubling of the previous figure is explained by the fact that most work camps and construction sites operated between July and September, during the time when students, who represented the backbone of the legionary movement, were on holiday.

71 In the first authoritative history of the legionary movement, Armin Heinen counted fifty work camps in 1936 - without, however, having access to Romanian archives. Heinen, Legiunea, 261. Rebecca Haynes, making use of data from the National Archives, mentions seventy-one work camps for the year 1936. Haynes, 'Work Camps,' 947. 
The work is also carried out by them. ${ }^{73}$ According to the author of this article, the involvement of peasants in these projects challenged the common perception of the rural population as 'lacking even the most elementary sense of initiative' and demonstrated instead that it can also show commitment to the public good, despite the lack of any encouragement from the authorities to this regard. ${ }^{74}$ This intensified interest in the rural environment, understandable in the context of a country where more than $70 \%$ of the population was involved in agriculture, ${ }^{75}$ renders the legionary movement's project of modernisation distinct both from the one undertaken by the interwar Romanian state, which was aimed at an accelerated urbanisation that would align Romania with Western Europe, and from other fascist regimes, as the Italian or German ones, where even the celebration of rural values was integrated into a vision that was manifestly that of an urban modernity. ${ }^{76}$ As such, even if the Legion was by no means either a 'peasant movement' or a political organisation with a conservative agenda, and its own modernist drive is clearly distinguishable both in the ideology and activities of the movement, the specific vision it put forth was emphatically that of a rural modernity, adapted to the realities of Romania in an attempt to remain true to what legionaries perceived as the 'authenticity' of the (predominantly rural) 'people' they claimed to represent. On a more practical note, given that most of the building projects lacked authorisation from the state authorities, it could be argued that the choice of rural locations made it more probable that they would pass unnoticed by local authorities, or that these would have less resources (and quite likely less willingness) to intervene.

Lastly, when approaching the available data according to geographical location, the legionary movement's claim that the work camps system was a nation-wide project appears justified: from the camp established in the village of Colniţa, in the north-western corner of Romania, to the one at Topleţ, in the south-western region of Banat, to the largest camp at Carmen Sylva, on the south-eastern littoral, or the one at Cernăuţi (Chernivtsi, in present-day Ukraine) in the north-eastern province of Bukovina, work camps were set up all across the country. The same pattern of distribution is also visible among the six largest camps as identified by Horia Sima: the Cluj camp in Transylvania,

73 Ion Ţurcan, 'Tabere şi şantiere' [Camps and construction sites], Însemnări sociologice [Sociological Notes], 2 (1936): 19.

74 Ion Ţurcan, 'Tabere şi şantiere', 19.

75 Henry Roberts, Rumania: Political Problems of an Agrarian State (New Haven: Yale University Press, 1951), 360-361.

76 See Roger Griffin, Modernism and Fascism: The Sense of a Beginning under Mussolini and Hitler (Basingstoke: Palgrave Macmillan, 2007). 
the Arnota camp in Oltenia, the Mount Rarău camp in Moldova, the Mount Susai / Predeal camp in Wallachia, the 'Green House' camp in Bucharest, and the Carmen Sylva camp in Dobrogea. ${ }^{77}$ However, the numerical distribution of the 130 camps identified in the Siguranţa report from 1937 also indicates that ninety-two of the camps ( $70 \%$ of the total) were established in the provinces that were part of the Old Kingdom of Romania, with only thirty-eight camps in the newly acquired provinces, although in terms of territorial size the latter were roughly equal to the Old Kingdom. In addition to the fact that Moldova was the place where the movement originated and consequently its initial stronghold, this distribution also indicates the movement's choice of locations where ethnic Romanians represented a majority of the population, avoiding the areas with considerable national minorities, an understandable preference for an ultra-nationalist movement and a further indication of the propaganda value of the camps. Of the areas with significant national minorities, Bessarabia, a highly contested region (simultaneously the region with the strongest communist organisations in interwar Romania and LANC's fief) where the first propaganda tours of the movement had been successful in 1930, had eight camps, the newly acquired province of Bukovina only three, while in southern Dobrogea, the territory acquired from Bulgaria after the First World War, there was only one camp, building a cultural centre in the village Cusuiul din Vale, in Durostor County. ${ }^{78}$ In Transylvania, no camps or construction sites were established in the three counties where ethnic Hungarians constituted the majority of the population. ${ }^{79}$

The number of legionaries working at these camps varied greatly, from a few that involved less than the specified minimum of thirty - demonstrating the propensity of the movement to circumvent its self-proclaimed 'principles' and 'rules' - through an average of fifty to one hundred legionaries to the several hundred people that worked in the bigger camps. The largest of them, the Carmen Sylva camp, established in 1935 and continued in 1936, saw eight hundred legionaries led by Codreanu himself working to build 'stone chalets and huts, ... six kitchens, a cellar, five fountains and a hen house', together with terraces

77 Sima, The History, 166.

78 CNSAS, Fund I, File 257486, Vol. 2, 377-394.

79 This information is derived from a map issued by the movement in 1940, during its time in power, showing the geographical distribution of the work camps and smaller construction sites. The map clearly shows conspicuous gaps in the areas with significant ethnic minorities, mostly in the border regions, but notably also in the three counties in central Romania where ethnic Hungarians were in the majority. See 'România Muncii Legionare' [The Romania of Legionary Work], http://www.miscarea.net/coloane.html, accessed 6 November 2013 . 
and drainage channels meant to consolidate the shore line, orderly paths and roads ( of which the largest one was named 'The Boulevard of the Romanian of Tomorrow'), as well as planting some five hundred trees and cultivating vegetables. ${ }^{80}$ Between 1 July and 30 August 1936, 718 men and 82 women, as well as fifty children sent to the camp by their parents, poor miners from Petroşani and Şorecani, worked at the camp. ${ }^{81}$ Even the children assisted with fishing, and the fish and shellfish that were not eaten by camp participants were sold for the benefit of the camp.

A typical daily schedule in one of the camps was the following: a trumpet wake-up call at 5:30am, gymnastics exercises from 6 to $7 \mathrm{am}$, breakfast at $7 \mathrm{am}$, work at the construction site from 7:30am to $1 \mathrm{pm}$, lunch from 1 to $2 \mathrm{pm}$, when the orders of the day were read, rest from 2 to $3 \mathrm{pm}$, work from 3 to $7 \mathrm{pm}$, dinner from 7 to $8 \mathrm{pm}$, civic education from 8 to $10 \mathrm{pm}$, lights out at $10 \mathrm{pm} .{ }^{82} \mathrm{On}$ Sundays and Christian holidays legionaries attended church service, and these were also the only days when visitors were formally received in the camps. ${ }^{83}$ The education of the youth in the work camps, combining physical and intellectual aspects, emphasised 'the new spirituality: Christian nationalism' that the legionary movement promoted. ${ }^{84}$ As such, the topics discussed as part of the 'civic education' carried out at the Storojineţ camp in Bessarabia between 1 and 15 August 1935 included: '(a) 1 . The dead of the Legion; (b) 1 . The attitude of the Legion towards the Church; 2. The Captain's letter; 3 . The importance of the work camps, the difference between legionary spirituality and "democratic" spirituality; (c) 1. The spirit of work in the Legion; 2 . Legionary discipline and camaraderie; 3 . The attitude of the legionary towards the world outside the Legion; 4. Legionary mysticism; 5 . The ten commandments of the legionary.' 85 Given the nature of the discussions, it is clear that these can be more accurately described as sessions of indoctrination, with the legionary movement seen as a microcosm that constituted the epitome of the envisaged fascist Romanian society. In this respect, the Carmen Sylva camp was directly identified by Gheorghe Macrin, one of the legionary intellectuals who wrote extensively

8o Haynes, 'Work Camps,' 959; Gheorghe Macrin, ‘Taberele de muncă: Tabăra de la Carmen Sylva' [The Work Camps: The Carmen Sylva Camp], Însemnări sociologice 1 (1936): 17-23.

81 Macrin, 'Taberele de muncă,' 21.

82 Gheorghe Macrin, 'O nouă şcoală românească: Taberele de muncă' [A New Romanian School: The Work Camps], Însemnări sociologice 1 (1935): 19.

83 Gheorghe Macrin, 'Taberele de muncă - aspectul politic' [The Work Camps - The Political Aspect], Însemnări sociologice 1 (1935): 22.

84 Macrin, 'O nouă şcoală,' 21.

85 Macrin, 'Taberele de muncă,' 22. 
about the work camps, as ' $a$ state in miniature'.86 Furthermore, in addition to demanding total commitment from its members, the 'education' imparted in the work camps emphasised constantly the radical opposition between the legionary movement and all democratic political parties in Romania, as well as its dismissal of the Romanian ruling elite as a 'parasitical class', 87 'dependent on forces foreign to the interests of the Romanian nation, such as Judaism and freemasonry'. 88 This was in line with the legionary ideological denunciation of democratic politics in general, invariably linked in the rhetoric of a movement that put forth an abstract representation of the 'Jew' as the arch-enemy of everything 'Romanian' to an alleged Jewish influence. ${ }^{89}$

As such, in spite of the fact that the success of the work camps prompted imitations by other political parties and even by the state, which will be discussed in more detail below, it comes as no surprise that the camps were eventually banned in the autumn of $1936 .{ }^{90}$ The closing of one of the last work camps, on Mount Susai near Predeal, where legionaries were building a mausoleum to the soldiers who had died in combat during the fighting on the former border between the Old Kingdom of Romania and the Austro-Hungarian Empire in the First World War, caused public outrage. On 5 September 1936, a troupe of two hundred gendarmes attacked the camp and destroyed the mausoleum that legionaries were building, desecrating the bones of the soldiers as well as several religious objects (icons, crucifixes, votive candles, a Gospel book) placed in the construction that was nearing completion. ${ }^{91}$ The story of the legionary work camps in interwar Romania thus ended the same way it began, with the arbitrary and brutal action of the authorities turning once again a hesitant public opinion in favour of the legionaries. The spectacular growth in popularity of the movement in the 1930s was eventually proven at the general elections of the following year, when the Totul Pentru Ţară ['All for the Country'] party, the political representative of the Legion, came third in the general elections, with $15.58 \%$ of the vote, a result that exceeded even the typically

\footnotetext{
86 Macrin, 'Tabăra dela Carmen Sylva,' 23.

87 Ibid., 12.

88 Macrin, 'Taberele de muncă,' 19.

89 See for example the following statement from Codreanu's programmatic memoirs: 'Money, the press, and votes are deciding over life and death in democracy. Jews have them all and through these, political parties become simple tools in the hands of the Judaic power.' Codreanu, Pentru legionari, 156.

$90 \quad$ Heinen, Legiunea, 262.

91 Codreanu, Circulări, 78-80.
} 
optimistic expectations of the legionary leadership. ${ }^{92}$ The mobilisation strategies employed by the movement in the course of the 1930s were pivotal for this electoral success, and among these, as will be argued below, the work camps system was one of the most important, if not the single most important such strategy.

\section{'Only One Ideology - the Deed'93: Work Camps as Mobilisation Strategies and Their Ideological Recoding}

Using Roger Eatwell's distinction between the 'esoteric and exoteric appeal' ${ }^{94}$ of fascist movements allows viewing their educational function within the legionary movement and their importance as a propaganda strategy as complementary. While previous authors have emphasised either of these purposes at the expense of the other, ${ }^{95}$ it is important to see them as performing equally important functions, albeit targeted at different groups. If for members of the organisation the primary role of the work camps was indeed one of 'education' (although 'socialisation' might be a better term, as will be shown below), the importance of their propaganda value for the general public cannot be underestimated. This complementarity was explicitly acknowledged by the legionary leadership, with Mihail Polihroniade stating in the introduction to the photography album entitled 'The Work Camp', published in 1936, that 'if for us the work camp is nothing but a school, for any honest-minded Christian it must represent a proof. A proof of the constructive spirit that animates the Romanian youth dressed in the green shirt. In this moment when everything is collapsing around us, we have set out to build. ${ }^{\prime 96}$ As legionaries were well aware, the evidence of youth carrying out voluntary construction work for the public

92 CNSAS, Fund P, File 11784, Vol. 9, 114. Ioan Scurtu et al., ed., Ideologie şi formaţiuni de dreapta în România, Vol. IV (1934-1938) [Right-wing Ideology and Movements in Romania] (Bucureşti: Institutul Naţional pentru Studiul Totalitarismului, 2003), 376.

93 Vasile Marin, 'O singură ideologie: fapta!' [Only One Ideology: The Deed!], Axa, 22 January 1933.

94 Eatwell, 'Towards a New Model,' 174.

95 In recent studies, both Rebecca Haynes and Valentin Săndulescu have emphasised their educational function aimed at creating the legionary 'New Man'. Haynes argues that 'The dissemination of legionary propaganda was not, of course, the primary function of the camps', while Săndulescu states that 'their educational character ... was the main goal of the work camps'. Haynes, 'Work Camps,' 948; Săndulescu, 'Taming the Body,' 89-9o.

96 Mihail Polihroniade, Tabăra de muncă [The Work Camp] (Bucureşti: Tipografia ziarului 'Universul', 1936), 1-2. 
good was bound to meet with a positive public reception, drawing to the movement not only new recruits but also sympathisers, some of which, particularly the intellectuals, were essential in providing the Legion with the 'good press' that is so badly lacked in its early years.

Consciously employed from the very beginning as an alternative to the movement's violent tactics, the projects were also symbolically emplotted as practical demonstrations of the palingenetic populist ideology of the Legion. The 'resurrection of Romania', which the movement proclaimed as its ultimate purpose ever since the first manifesto posted on the walls of Iaşi a few days after its establishment, ${ }^{97}$ was always at the centre of legionary rhetoric, and it was to be 'proven' (to use Polihroniade's terminology) to the public through the construction of a new Romania based on fascist principles, permanently contrasted with the alleged corruption and decadence of democratic politics and the consequent 'fallen' state of the country: 'We want to build: from a collapsed bridge to a highway and the transformation of a waterfall into hydraulic power, from the building of a new peasant household to that of a new village, a new city, a new Romanian state. This is the historic calling of our generation: on the ruins of today, to build a new country, a proud country.'98 This permanent dichotomy through which the legionary movement emphasised its novelty (both ideological and at the level of mobilisation strategies) and presented itself as the only solution to the crisis of Romanian democracy in the 1930s was at the same time a consistent strategy for undermining the government and challenging the existing elites, as well as a constituent part of its intransigent ultra-nationalism which posited an 'us and them' divide as the fundament of all politics. In this respect the Legion was reproducing a pattern that Stanley Payne identifies as characteristic of fascist movements, the belief that 'decadence could only be overcome through a revolutionary new culture led by new elites, who would replace the old elites of liberalism and conservatism and of the left:.99 Consequently, as shown in numerous occasions above, any legionary endeavour, as minor or unpromising as it could have been, was always juxtaposed to the failure of the government to address a certain issue. As the enthusiasm of the population for the post-war enlarged Romanian state faded by the 1930s against the backdrop of the economic crisis, the government (and democratic politics in general) came to be viewed with increasing suspicion, opening up the political space to radical alternatives such as the legionary one. Promoting alternative forms of political participation that emphasised

\footnotetext{
97 ANIC, Fund MI, File 2/1931, 6.

98 Codreanu, Pentru legionari, 462 (emphasis added).

99 Payne, $A$ History of Fascism, 9.
} 
grassroots mobilisation and voluntarism, corresponding to an activist ideology that criticised the sterility of parliamentary debate, the legionary movement interpreted their work camp system as both a laboratory for the creation of its own fascist elite (esoterically) and an exemplary model of their project for the modernisation of Romania (exoterically).

Within legionary ideology, manual labour was seen to have a redeeming effect, as a practical manifestation of the spirit of sacrifice and discipline that would deliver the legionaries from the useless complexities of modern life and accustom them to the harsh and simple life of the fascist. ${ }^{100}$ Labour was described as necessary and essential for the 'new man', and contrasted to the parasitic exploitation of the establishment: 'In the work camp, Romanian youth learns that no one has the right to live without work, making use in parasitic manner of the fruit of the work of others.'101 This was seen as especially important for intellectuals, who would thus 'resume contact with physical effort, [and] become accustomed to the everyday toil of the peasant and of the worker.'102 Such an appeal to the intellectuals to engage in manual labour is by no means unique to the Romanian case, and is reminiscent of Martin Heidegger's appeals to the students in Germany. Referring to Heidegger's view of the National Socialist labour service, Michael Gillespie states that 'such service provides the basic experience of hardness, of closeness to the soil and to the implements of labour, of the rigorous law that governs the simplest physical labour in a group. As a result, the differences between intellectual work and handiwork disappear.'103 All the terms used in this statement recall Polihroniade's formulations, as is the general notion that 'it is only in this way that the individual is rooted in the people as a whole.' ${ }^{104}$ However, the specific difference of the Romanian work camps from the Nazi ones lies in the fact that they were developed not as state projects (although they would eventually be imitated by the state, with much less success), but as institutions that were at least parallel, if not in outright opposition to the state. Moreover, the typical fascist interpretation of manual labour as redeeming had a pronounced appeal in a country like Romania, where the overwhelming majority of the population was still employed in manual labour.

\footnotetext{
100 Polihroniade, Tabăra de muncă, 1.

101 Ibid.

102 Ibid.

103 Michael A. Gillespie, 'Martin Heidegger's Aristotelian National Socialism,' Political Theory 28 (2000), 156-157.

104 Gillespie, 'Martin Heidegger's,' 156.
} 
The integration of the individual within the nation was also to take place through the cross-class and inter-regional solidarity of Romanians from all social categories and provinces of Greater Romania. The camp brought together, 'in the service of the same ideal, scholars and peasants, workers and students, artisans and graduates .... people from Moldova and Oltenia, Dobrogea and Banat, Maramureş and Oltenia, Bukovina and Bessarabia'. ${ }^{105}$ The legionaries working at the 'Iancu Flondor' camp in Storojineţ County (building a village cultural centre) included fourteen workers and artisans, ten students, two high school teachers, two primary school teachers, two doctors, two lawyers, one landowner, one university professor, and one peasant, making up a total of thirty-five participants in the camp, led by the pharmacist Vasile Iasinschi. ${ }^{106}$ At the 'Traian Brăileanu' camp established in the town of Rădăuţi, building a church having the Archangel Michael as its titular saint, out of 630 legionaries 436 were peasants, seventy-two workers, fifty artisans, twenty-nine students, seven high school pupils, six teachers, six lawyers, five licentiates, four public servants, two pharmacists, two priests, and one university professor. ${ }^{107}$ Finally, at the largest and most representative of the work camps, the Carmen Sylva one, there were 170 students, sixty-five university graduates, sixty-five workers and artisans, fifty-nine public servants, fifty-six peasants, thirty-eight high school pupils and thirty-three high school graduates, thirty-three lawyers, thirty-two teachers, twenty university professors, sixteen tradesmen, seven engineers, four journalists, four writers, four priests and three church singers, four airplane pilots, one architect, one sculptor, and one painter. ${ }^{108}$

The purpose and final outcome of this process of socialisation in the camps was seen as 'unity through love and discipline', the fundamental principle that Codreanu himself posited as both the means and the ultimate end of the legionary ideal. ${ }^{109}$ Just as the work camps were intended to socialise legionaries in the spirit of cross-class solidarity, for outsiders to the Legion this was interpreted as evidence of the 'brotherhood' of members of the organisation, itself seen as a model for that of the future Romanian nation. In a country where the integration of the provinces acquired after the First World War into the

105 Polihroniade, Tabăra de muncă, 1.

106 Macrin, 'Taberele de muncă,' 21.

107 Tुurcan, 'Tabere şi şantiere,' 16. For ten of the participants in the camp, their profession was not specified. It is also interesting to compare the two examples above, showing more people from the urban environment working at a village camp, and more peasants working at an urban camp - although the religious purpose of the latter building might also explain the higher proportion of peasants at the camp.

108 Macrin, 'Tabăra dela Carmen Sylva,' 20.

109 Polihroniade, Tabăra de muncă, 1. 
Romanian state was far from complete and where the land redistribution of 1921 had failed to solve the problem of widespread poverty in the countryside, the image of members of the traditional aristocracy, professionals, intellectuals, workers and peasants working side by side towards a common purpose was a very powerful one indeed, and one that was thoroughly exploited by legionary propaganda. In this respect, the work camps were re-coded back into legionary rhetoric as practical illustrations of the cross-class and inter-regional appeal of the Legion, adding weight to its claim to constitute a nation-wide movement. One legionary commander wrote with reference to the smaller şantiere 'that they structure and deepen the beginning of a strong Romanian solidarity', 'crystallising the consciousness of belonging to a community', understood in the typical legionary ideological terms of a 'moral community'.110

The popularity of the work camps can also be inferred from the growing number of visitors that came to the camps. At the relatively small rural camp in Storojineţ County, in the province of Bessarabia, the number of visitors grew from none on the first sunday after the camp was open to twenty on the second and approximately two hundred on the third sunday. ${ }^{111}$ The larger camp of Carmen-Sylva was visited not only by Romanians (among which were prominent public figures, such as Nae Ionescu, one of the mentors of the selfentitled 'new generation' of Romanian intellectuals), but also by foreigners Germans, Poles, Czechs, and Yugoslavs. ${ }^{112}$ Police reports noted that visitors to the camps were positively impressed, a fact that can also be inferred from the fact that many of them became donors - for example, a small camp had more donors (fifty) than participants (thirty-five). ${ }^{113}$ As such, it is clear that the work camps were not merely aimed at socialising and indoctrinating the participants, but also at attracting public support, on which their very existence often depended. Their double function was explicitly acknowledged by legionary commentators who wrote about the subject: 'The work camps are not only exerting their influence on the Legionaries, on those who receive their education there. They are also an admirable means of educating public opinion and [civic] spirit .... There is no visitor, regardless of his political beliefs, that passed through a camp without being amazed of what he saw there. Almost every visitor thought to support with his contribution this novel activity in the

\footnotetext{
110 Ţurcan, 'Tabere şi şantiere,' 20.

111 Macrin, 'Taberele de muncă,' 21.

112 Macrin, 'Tabăra dela Carmen Sylva,' 20.

113 Macrin, 'Taberele de muncă,' 21; Note of the Constanţa Siguranţa Bureau, 22 July 1935. Cited in Scurtu et al., ed., Ideologie, Vol. IV, 114.
} 
life of our Nation.'114 In fact, this favourable perception of the legionary work camps could also be encountered among the authorities that were responsible for their surveillance. The aforementioned police report referring to the Carmen Sylva camp clearly shows the sympathy of its author, who stated that 'it is not true that the guardists have provoked scandals in the resort .... The unfavourable atmosphere created around the Iron Guard is due to the deputy mayor Rozeanu, who was formerly called Rosenblatt.'115 Such a statement corresponds to the typical legionary reaction to any criticisms of the work camps these were often answered with the common stereotype that such allegations were devised by Jews.

The importance of the camps for the legionary organisation can be inferred not only from the extensiveness and popularity of this project across Romania, but also from the fact that Codreanu specified in a circular that no member of the organisation could become a legionary or accede to any rank within the movement without having participated in a camp. ${ }^{116}$ Making a distinction between simple members in the organisation and the elite core of legionaries, the instructions issued in June 1935 by General Gheorghe Cantacuzino - head of the 'All for the Country' party - mentioned participation in a work camp or construction site as the first precondition for becoming a legionary. ${ }^{117}$ And if the ban on the work camps only resulted in a concentration of legionary efforts toward another practical propaganda strategy, the project of legionary commerce - which itself originated with the small legionary shops and canteens operating in the work camps -, the banning of the latter project led Codreanu to issue an open letter of protest against the Minister of the Interior, which in turn led to his subsequent imprisonment and eventual assassination by representatives of the government. ${ }^{118}$

At the same time, the success of the legionary work camps prompted imitations, first and foremost by members of the rival radical right organisation, LANC. ${ }^{119}$ These were however far less popular than their legionary counterparts. ${ }^{120}$ A yet more interesting imitation of the legionary work camps can be found in King Carol II's funding of the 'student teams' led by the sociologist

\footnotetext{
114 Ţurcan, 'Tabere şi şantiere,' 10.

115 Scurtu, Ideologie, Vol. IV, 114.

116 Codreanu, Circulări, 41.

117 CNSAs, Fund I, File 257486, Vol. 2, 101.

118 Raul Cârstocea, 'The Role of Anti-Semitism in the Ideology of the Legion of the Archangel Michael' (PhD Thesis, University College London, 2011), 121-122, 141-149.

119 ANRM, Fund DGP, File 44/1927, 203-204.

120 See for example Scurtu, Ideologie, Vol. IV, 114. The aforementioned police report addressing legionary propaganda in the last six months of 1936 explicitly identified work camps
} 
Dimitrie Gusti, which were deployed to the countryside starting from 1934, as well as in the government's attempt to establish 'compulsory work camps' in 1936. ${ }^{121}$ These developments can be understood as part of the king's efforts at becoming the leader of the country's youth. Straja Ţării [The Sentinel of the Country], a scouting organisation, was also established in 1934 in an attempt of King Carol II to counter the growing influence of the Legion 'by using its own tools' and to enlist the country's youth in a state-controlled project. ${ }^{122}$ The very word strajă [sentinel] is a synonym of 'guard', and the names given to units of the organisation (the smallest one was a 'nest', the largest one a 'legion') are also indicative of the attempt to imitate the legionary movement. ${ }^{123}$ The king's attempts were largely unsuccessful, in spite of the considerable funds invested in these organisations. As Constantin Argetoianu, one of the prominent democratic politicians loyal to King Carol II, pointed out in a conversation with the king in November 1937, 'the youth is disciplined through the formations belonging to Straja Ţării and Pre-military Education, but to whose benefit? Where does this disciplined and militarily trained youth go? They all go to our different parties, but especially to the Iron Guard. Thus, in the end, Straja Ţării becomes an institution of recruitment for Zelea Codreanu. ${ }^{\prime 24}$

Codreanu was wary of these imitations, and careful to point out that the legionary work camps project was not an imitation itself, not only with regards to other political organisations in Romania, but also to the labour services in the two established fascist regimes in interwar Europe: 'The work camp is a new school; a school of ours, our own, born from our Romanian land and soul.

as a 'form of organisation specific to this movement' and as the most important type of legionary activity. CNSAS, File I 257486, Vol. 2, 377 .

121 See Curierul echipelor studenţeşti [The Courier of Student Teams], 1935-1938, and Curierul serviciului social [The Courier of the Social Service], 1939. Both these publications extensively employ legionary terms: camarazi [comrades], tabere de muncă [work camps], etc. For a criticism of these initiatives as 'plagiarisms' and 'sinister parodies' of legionary practices, see Leon Ţopa, 'Taberele de muncă obligatorie' [The Compulsory Work Camps], Însemnări sociologice 2 (1936): 24-29.

122 Raluca Muşat, 'Sociologists and the Transformation of the Peasantry in Romania, 1925-1940' (PhD Thesis, University College London, 2011), 198-199.

123 Ibid., 199. See Gheorghe Manoilescu et al., 'Straja Ţării' [The Sentinel of the Country], in Enciclopedia României, Vol. 1 [The Encyclopedia of Romania, Volume 1], (Bucureşti: Imprimeria Naţională, 1938), 482-490.

124 Constantin Argetoianu, Insemnări zilnice, Vol. 3 (1 iulie 1937 - 31 decembrie 1937) [Daily Notes, Volume 3, 1 July 1937 - 31 December 1937], ed. Stelian Neagoe, (Bucureşti: Editura Machiavelli, 2001), 217. Police reports confirm this statement, mentioning cases where instructors in the state pre-military education system were openly carrying out legionary propaganda. CNSAS, Fund I, File 257486, Vol. 2, 413. 
It is not an imitation, because in 1924, when I started the brickworks at Ungheni and the student dormitory at Iaşi, it was not used either in Italy or in Germany.'125 Other legionary authors were also extremely vocal in their criticism of the government's attempts to replicate the Legion's system of work camps, referring to the government-sponsored work projects as 'concentration camps or perhaps forced labour camps' and emphasising the contrast with the voluntary and self-funded nature of the legionary endeavours. ${ }^{126}$ The leader of the Bacău chapter of the 'All for the Country' party went even further, denouncing King Carol II's scouting as a 'purely freemason institution, of universal fraternity (with the Jews), pumping millions of lei yearly'.127

In addition to the grassroots propaganda carried out at the camps and construction sites, the press coverage dedicated to them in legionary and other right-wing publications was considerable. Extensive presentations of the legionary work camps combined general assessments and theoretical conceptualisations of their implication according to the legionary ideological code with numerous examples and countless illustrative photographs. One of the only two albums of photographs issued by the legionary movement during the interwar period was compiled by Mihail Polihroniade in 1936 and entitled 'The Work Camp', 128 and imagery associated with the work camps also featured prominently on legionary calendars (another effective means of propaganda in the rural environment), postcards, and even electoral posters for the 1937 general elections. ${ }^{129}$ Even one of the oldest and more respectable nationalist weeklies in Transylvania, Libertatea [Freedom], became a 'green paper' at this time, and dedicated a permanent section to the constructive projects of the legionaries. ${ }^{130}$

125 'Spre o lume nouă' [Toward a New World], Braţul de fier [The Iron Arm] 1 (1935): 2.

126 Macrin, 'Tabăra dela Carmen Sylva,' 13. See also Ţopa, 'Taberele,' 24-29.

127 Alexandru Ciulei, 'Scurtă privire asupra nevoilor şi suferinţelor româneşti' [Brief Overview of the Romanian Needs and Sufferings], Braţul de fier 1 (1935): 3. Leu (plural lei) was and still is the name of the Romanian currency.

128 The other was entitled 'Dezordinile' dela Târgu Mureş [The 'Disorders' at Târgu Mureş] and documented in dozens of photographs the 'orderly' fashion in which the legionary students had behaved during a student congress that took place in Târgu Mureş, notorious among other things for the establishment of legionary 'punishment teams' meant to assassinate the movement's opponents. I am grateful to an anonymous reviewer for drawing my attention to this publication.

129 ANIC, Fund MI, File 8/1936, 108; File 13/1937, 100-101, 106-108.

130 'Libertatea - foaie verde' [Freedom - Green Paper], Libertatea [Freedom], 12 April 1936. It should be mentioned that Ioan Moţa, the editor of Libertatea, was the father of Ion I. Moţa, a founding member of the legionary movement and Codreanu's unofficial lieutenant. 
Finally, given that many of the constructive work projects involved ecclesiastical property, the support of the clergy for the work camps became yet another important factor in securing the sympathy of a population that was often fervently religious. The endorsements of these projects by prominent figures of the Orthodox Church were very significant, with Metropolitan Gurie of Bessarabia stating: 'Deeply impressed by the organisation of legionary youth, students, intellectuals, and common people for constructive work, ... we give our blessing to this direction embraced by them and implore the help of God for the strengthening, extension and growth of the legionary organisation, which has a purely Christian character. ${ }^{131}$ Similar statements were made by Bishop Vartolomeu of Oltenia, Bishop Visarion of Hotin, and Bishop Nicodim of Moldova. ${ }^{132}$ The involvement of clergy in the work camps, particularly in the services marking the inauguration or closing of the camps and in the various religious ceremonies celebrated there (legionary weddings, baptisms), was also very important, especially for the peasant population. As Rebecca Haynes acknowledges in her article focusing on the educational function of the work camps, 'Clearly, the Legion fully exploited their links with priests, as well as local lawyers and teachers, who lived in the vicinity of the camps. It was, after all, this sector of society which enjoyed "an unchallenged authority amongst the population"'.133 However, the attitude of the clergy towards the legionary work camps was not always one of support, particularly among the higher ranks of the Orthodox Church hierarchy. As such, antedating the government ban on work camps in 1936, on 23 October 1935 the Orthodox Patriarch Miron Cristea forbade priests from supporting these projects on grounds specifying that 'under the cover of voluntary work, they are only aimed at attracting the popular masses toward guardist ideas.' ${ }^{134}$ The propaganda value of the work camps was thus not lost on the leadership of the Orthodox Church, which traditionally maintained close links to the state authorities and consistently backed their political positions. However, the fact that the majority of work projects carried out in 1936 ( $39 \%$ of the total) still involved ecclesiastical property demonstrates the ineffectiveness of the bans issued by the Patriarch, and the considerable

However, while Libertatea had been published since 1902, it was only in 1936 that the newspaper openly declared its support for the legionary movement.

132 Ibid.; ANIC, Fund DGP, File 239/1935, 1.

133 Haynes, 'Work Camps,' 957.

134 ANIC, Fund DGP, File 239/1935, 1. 
involvement of the lower clergy in the legionary movement, in turn contributing significantly toward its growing popularity, especially in rural areas.

\section{Conclusion}

A comprehensive analysis of the legionary work camps system needs to take into account their two complementary functions, of socialisation of members within the movement and of propaganda directed at the general public. Developed out of the consistent preference of the movement for grassroots mobilisation strategies, in turn partly driven by an initial lack of funding that prevented it from competing with the more established democratic political parties in interwar Romania, the work camps were at once envisioned as practical examples of the voluntaristic, activist ideology the Legion promoted and as tools for further integration, of its own members within the organisation and ultimately of the Romanian nation as a whole. They were also conceptualised as the beginnings and the standing 'proofs' of the alternative project of modernisation that the legionary movement promoted and which was further developed with the practices of legionary commerce, agriculture, and even the beginnings of a legionary industry. ${ }^{135}$ In its palingenetic drive and populist ultra-nationalist overtones, this project was a distinctly fascist one, recoded ideologically as 'The Revolution of the Resurrection of the Romanian Nation.'136

As a constituent part of this fascist project of building a 'new' Romania, perhaps its most important one, the work camps system, while strategically devised from the very beginning to counteract the accusations of promoting violence and representing a threat to the stability of the Romanian state, was never as non-violent as the leaders of the organisation claimed it to be. Although claiming and to a considerable extent succeeding to accomplish the cross-class and inter-regional solidarity of the participants to the work camps, as well as managing to mobilise public support for them, the legionary voluntary work system ultimately promoted a much more radical and exclusionary nationalist project than the one that the Romanian state embarked upon during the interwar period. Born among the anti-Semitic student movements of the 1920 just as the Legion itself, the work camps were consistently conceptualised as reactions against a capitalist exploitation that was invariably linked

\footnotetext{
135 See Haynes, 'Work Camps,' 960-966; Cârstocea, 'The Role of Anti-Semitism,' 119-122, 220-224.

136 Ţurcan, 'Tabere şi şantiere,' 22. For theoretical interpretations of fascism that emphasise its revolutionary character, see Griffin, The Nature of Fascism; Payne, A History of Fascism.
} 
to the Jewish minority. Numerous police reports mention General Cantacuzino's speeches during his visits of various camps (Storojineţ, Carapciu, Igeşti, Rădăuţi), in which he reiterated the legionary virulent anti-Semitic stance. ${ }^{137}$ Some of these addresses contained direct instigations to murder the 'Jews and the Jewified', sometimes even employing the term 'extermination'.138 In addition to the anti-Semitic propaganda carried out at the camps, a quasi-military discipline was applied throughout the camps, with marches in military formation and other forms of military instruction often included among the activities, ${ }^{139}$ in line with Codreanu's expressed preference for the paramilitary organisation of youth and his vision of the legionary movement as 'more of $a$ school and an army than a political party.'140

Finally, the frequent use of violence by the authorities against participants in the work camps and the constant surveillance of the police of what were in all appearance peaceful constructive work projects allowed the Legion to protest against their brutality and arbitrariness and consequently rally under its banner a public that was all too familiar with customary police abuse. Nevertheless, as shown above, in spite of all its claims to the contrary the legionary work camps were a markedly subversive, anti-state endeavour. Every minor legionary achievement was consistently juxtaposed to the failure of the government to address a certain issue and the construction of a 'new' Romania in accordance with fascist principles was permanently contrasted with the corrupt state of Romanian democracy. In both their esoteric socialisation function and the exoteric propaganda one, work camps deepened the rift between a disillusioned people and its ruling elites, which the legionary movement carefully exploited. As such, in line with the legionary ideological outlook putting forth a dichotomic, 'us versus them' vision of politics in which all of the Legion's enemies were consistently associated with an alleged 'Jewish influence', the work camps, as arguably the most important mobilisation strategy employed by the movement, gradually contributed to a radicalisation of the Romanian interwar political space, witnessing a move from the grassroots contestation of the government in power to the eventual de-legitimisation of the principles of democratic government itself. Ironically then, when King Carol II eventually brought to an end Romania's problematic interwar democracy and proclaimed his royal dictatorship in 1938, one that borrowed among other fascist trappings

\footnotetext{
137 CNSAS, Fund I, File 257486, Vol. 2, 125-127, 224-226, 397-398, 417-418, 420.

138 Ibid., 418, 420.

139 Ibid., 409.

140 Codreanu, Pentru legionari, 307.
} 
the grassroots mobilisation impetus characteristic of the legionaries, they were to be among its first and most numerous victims.

Although clearly limited to its specific historical context, the present paper might show its contemporary relevance when taking into consideration current concerns regarding voter apathy and participation to the political process in liberal democratic states, and the promotion of alternative forms of political participation (such as grassroots, voluntary associations or social movements) over political parties. Considered also against the background of the contemporary resurgence of radical right organisations, many of which make extensive recourse to grassroots propaganda strategies in their quest for popularity (the food handouts of Golden Dawn in the context of the economic crisis affecting Greece being just one such example), such research might thus reveal a darker side of forms of mobilisation that are typically hailed as inherently positive, not least since contemporary right-wing groups often look for inspiration to their interwar predecessors. Perhaps paradoxically given the prevalent faith in civil society as a democratic force in post-communist states, and in line with recent interpretations of fascism focusing on its 'civic foundations,', ${ }^{141}$ further research on this subject might thus be warranted not only by the need to bring into question the past, but also to understand, and potentially prevent, a radical return in the present.

141 See Dylan Riley, The Civic Foundations of Fascism in Europe: Italy, Spain, and Romania, 1870-1945 (Baltimore: Johns Hopkins University Press, 2010). 